\title{
First molecular evidence of Borrelia burgdorferi sensu lato in goats, sheep, cattle and camels in Tunisia
}

\author{
Mourad Ben Said ${ }^{1}$, Hanène Belkahia ${ }^{1,2}$, Alberto Alberti ${ }^{3}$, Khaoula Abdi ${ }^{4}$, Manel Zhioua ${ }^{1}$, \\ Monia Daaloul-Jedidi', Lilia Messadi ${ }^{1}$ \\ ${ }^{1}$ Laboratoire de Microbiologie, Ecole Nationale de Médecine Vétérinaire, Université de La Manouba, Tunisia \\ ${ }^{2}$ Faculté des Sciences de Bizerte, Université de Carthage, Tunisia \\ ${ }^{3}$ Dipartimento di Medicina Veterinaria, Università degli Studi di Sassari, Italy \\ ${ }^{4}$ Laboratoire de Biotechnologie et Valorisation des Bio-Géo Ressources, Institut Supérieur de Biotechnologie de Sidi \\ Thabet, Université de La Manouba, Tunisia
}

\begin{abstract}
Ben Said M, Belkahia H, Alberti A, Abdi K, Zhioua M, Daaloul-Jedidi M, Messadi L. First molecular evidence of Borrelia burgdorferi sensu lato in goats, sheep, cattle and camels in Tunisia. Ann Agric Environ Med. 2016; 23(3): 442-447. doi: 10.5604/12321966.1219184
\end{abstract}

\section{Abstract}

Borrelia burgdorferi sensu lato (s.l.) are tick-transmitted spirochaetes of veterinary and human importance. Molecular epidemiology data on ruminants are still lacking in most countries of the world. Therefore, the aim of this study was to estimate the rate of $B$. burgdorferi s.l. infection in ruminants from Tunisia. A total of 1,021 ruminants (303 goats, 260 sheep, 232 cattle and 226 camels) from different bioclimatic areas in Tunisia were investigated for the presence of $B$. burgdorferi s.I. DNA in blood by real time PCR. Prevalence rates were $30.4 \%(92 / 303)$ in goats, $6.2 \%(16 / 260)$ in sheep, $1.3 \%(3 / 232)$ in cattle, and $1.8 \%(4 / 226)$ in camels. Only tick species belonging to Rhipicephalus and Hyalomma genera were found on the investigated animals. In small ruminants, the prevalence of $B$. burgdorferi s.l. varied significantly according to localities and farms. Goats located in humid areas were statistically more infected than those located in sub-humid areas. Prevalence rates varied significantly according to age and breed in sheep, and age and tick infestation in goats. This study provides the first insight into the presence of $B$. burgdorferi s.I. DNA in ruminants in Tunisia, and demonstrates that host species such as goats and sheep may play an important role in natural Lyme disease cycles in this country.

\section{Key words}

Borrelia burgdorferi sensu lato, ruminant species, molecular evidence, risk factors, Tunisia

\section{INTRODUCTION}

Lyme borreliosis, a zoonotic tick-borne disease caused by spirochaetes of the group B. burgdorferi sensu lato, is a multi-organ disease of mammals widespread in the northern hemisphere [1]. The clinical form of Lyme borreliosis occurs in humans and domestic animals, especially dogs, horses, and cattle $[2,3,4]$. Borrelia burgdorferi s.l. includes at least 19 genospecies, with 5 of them known to be pathogenic for humans: Borrelia burgdorferi sensu stricto (s.s.), Borrelia afzelii, Borrelia bavariensis, Borrelia garinii and Borrelia spielmanii $[5,6,7,8]$.

Most reports on Lyme borreliosis in domestic animals focus on dogs and horses $[3,4]$ and only few descriptions of infection in cattle and sheep are available $[9,10]$. In cattle, lyme borreliosis was reported in the 1980s in the USA $[2,11]$. The predominant clinical signs of infection included lameness, weight loss and abortion. A few cases of B. burgdorferi s.l. infection have been reported in sheep, with lameness, anorexia, and poor body condition [10].

Although most ruminants are considered as incompetent reservoirs [12], they have some importance in the ecology and dynamics of the circulation of $B$. burgdorferi s.l., especially by acting as maintenance hosts for tick populations, as spreaders of infected ticks [13], or as a potential host of

Address for correspondence: Lilia Messadi, Laboratoire de Laboratoire de Microbiologie,Ecole Nationale de Médecine Vétérinaire, 2020 Sidi Thabet, Tunisie E-mail: lilia_messadi@yahoo.fr

Received: 11 September 2015; accepted: 15 December 2015 ticks that could infect themselves by co-feeding, as observed in sheep $[14,15]$.

This complex has been weakly investigated in Tunisia, and its current geographic distribution remains unknown. Ixodes ricinus ticks, the main vector of $B$. burgdorferi s.l. in Europe, are abundant in the humid regions of Tunisia [16], and are very frequently infected by Borrelia lusitaniae [17, 18], a species which although considered non-pathogenic has been isolated from a patient in Portugal [19].

Several direct and indirect methods are used for detecting the $B$. burgdorferi s.l. complex. Indirect methods, mainly serological, are based on antibody detection [20]. Direct methods detect the bacteria or its components. The methods most often used are culture, microscopy and molecular; indeed, DNA detection by PCR has been acclaimed for its high sensitivity and specificity $[21,22]$.

\section{OBJECTIVE}

To the best of our knowledge, no information is available on the presence of $B$. burgdorferi s.l. complex in ruminants in Tunisia. Therefore, this study aims to understand the role of ruminants as carriers and potential spreaders of Lyme disease in this country. The exposure of several ruminants' species to B. burgdorferi s.l. complex was investigated using Real time PCR while also taking into account geographic and host-relating factors. 


\section{MATERIALS AND METHOD}

\section{Ruminant populations and study regions}

Sheep. In May 2011, blood samples were collected from 260 randomly selected sheep which belonged to 9 herds situated in 2 localities of the governorate of Bizerte, a sub-humid bioclimatic area with a mean annual rainfall of $400 \mathrm{~mm}$ : El Alia $\left(37^{\circ} 16^{\prime} \mathrm{N}, 10^{\circ} 03^{\prime} \mathrm{E}\right)$ and Khetmine (latitude $37^{\circ} 16^{\prime} \mathrm{N}$, longitude $9^{\circ} 99^{\prime} \mathrm{E}$ ) (Fig. 1). The sheep belonged to 6 breeds: Barbarine (118), Noire de Thibar (82), Queue Fine de l'Ouest (10), Merinos (2), Sicilo-sarde (1) and cross-breeds (47). Gender ratio (male/female) was 0.24 and mean age $4.9 \pm 2.0$ years.

Goats. Blood sampling was performed from May to September 2013 on 303 apparently healthy goats from 16 herds situated in 4 localities of the Bizerte and Beja governorates: El Alia (Governorate of Bizerte, latitude $37^{\circ} 16^{\prime} \mathrm{N}$, longitude $10^{\circ} 03^{\prime}$ $\mathrm{E})$, belonging to the sub-humid bioclimatic area, Joumine (Governorate of Bizerte, latitude $36^{\circ} 92^{\prime} \mathrm{N}$, longitude $9^{\circ} 38^{\prime} \mathrm{E}$ ), Sejnane (Governorate of Bizerte, latitude $37^{\circ} 15^{\prime} \mathrm{N}$, longitude $9^{\circ} 23^{\prime} \mathrm{E}$ ), and Amdoun (Governorate of Beja, latitude $36^{\circ} 76^{\prime} \mathrm{N}$, longitude $\left.9^{\circ} 08^{\prime} \mathrm{E}\right)$. The 3 latter localities belong to the humid bioclimatic area with a mean annual rainfall of $650 \mathrm{~mm}$ (Fig. 1). Goats breeds were: a local breed $(n=275)$, Alpine $(n=23)$ and Maltese $(n=5)$. Goats' gender ratio (male/female) was 0.3 and mean age $3.9 \pm 1.7$ years.

Cattle. From July to December 2012, blood was collected from 232 randomly selected cattle in 36 farms situated in three localities of the Bizerte governorate in northern Tunisia: Utique (latitude $37^{\circ} 16^{\prime} \mathrm{N}$, longitude $9^{\circ} 52^{\prime} \mathrm{E}$ ) belonging to the semi-arid bioclimatic area with a mean annual rainfall of $400 \mathrm{~mm}$, El Alia (latitude $37^{\circ} 16^{\prime} \mathrm{N}$, longitude $10^{\circ} 03^{\prime} \mathrm{E}$ ) and Mateur (latitude $37^{\circ} 02^{\prime} \mathrm{N}$, longitude $9^{\circ} 39^{\prime} \mathrm{E}$ ) belonging both to the sub-humid bioclimatic area with a mean annual rainfall of $600 \mathrm{~mm}$ (Fig. 1).

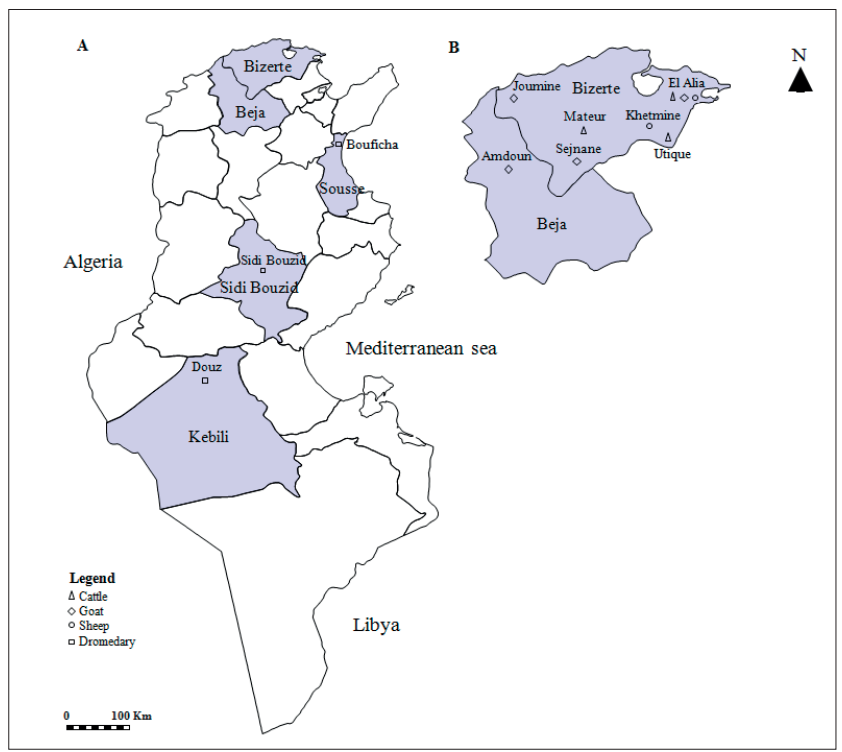

Figure 1. Map of Tunisian studied localities

A. Map of Tunisia showing location of the governorates of Bizerte, Beja and the localities of Bouficha, Sidi Bouzid and Douz located in the governorates of Sousse, Sidi Bouzid and Kebili, respectively. B. Map of Bizerte and Beja governorates showing the location of El Alia, Khetmine, Utique, Mateur, Joumine, Sejnane and Amdoun localities
Camels. From May to October 2009, blood sampling was performed on 226 apparently healthy camels situated in 3 localities: Bouficha (Governorate of Sousse, latitude $36^{\circ} 18^{\prime} \mathrm{N}$, longitude $10^{\circ} 27^{\prime} \mathrm{E}$ ) belonging to the semi-arid bioclimatic area with a mean annual rainfall of $350 \mathrm{~mm}$, Sidi Bouzid (Governorate of Sidi Bouzid, latitude $35^{\circ} 0^{\prime} \mathrm{N}$, longitude $9^{\circ} 29^{\prime} \mathrm{E}$ ) belonging to the arid bioclimatic area with a mean annual rainfall of $237 \mathrm{~mm}$, and Douz (Governorate of Kebili, latitude $33^{\circ} 27^{\prime} \mathrm{N}$, longitude $9^{\circ} 01^{\prime}$ E) belonging to the Saharan bioclimatic area with a mean annual rainfall of $89 \mathrm{~mm}$ (Fig. 1).

Blood sampling, tick collection and DNA extraction. Blood samples were collected from the jugular vein into EDTA tubes (Becton Dickinson). For each ruminant, the studied region, approximate age, gender, breed and presence or absence of ticks, were noted. Ticks were collected from all animals, preserved in $70 \%$ ethanol and identified to genus and species levels by using the taxonomic keys of Walker et al. [23]. DNA was extracted from $300 \mu$ l of EDTApreserved whole blood using the Wizard ${ }^{\circledR}$ Genomic DNA purification kit (Promega, Madison, USA), according to the manufacturer's instructions. DNA yields were determined with a spectrophotometer (Jenway, Genoa, Italy). Isolated DNA was stored at $-20^{\circ} \mathrm{C}$ until use.

Real time PCR detection of Borrelia burgdorferi sensu lato. All ruminants were screened for the presence of $B$. burgdorferi s.l. by using complex-specific primers and a TaqMan probe, as described by Courtney et al.[22]. A 75-bp fragment was amplified in the B. burgdorferi s.l. 23S rRNA gene. Real time PCR was performed using Premix Ex Taq ${ }^{\mathrm{Tm}}$ (Perfect Real Time) (Takara, Mirus Bio, Madison, WI, USA) in a 7500/7500 Fast Real-Time PCR System quantitative thermal cycler (Applied Biosystems, USA). PCR amplification was performed in a simplex format by optimal reaction conditions using primers $\mathrm{Bb} 23 \mathrm{Sf}$ and $\mathrm{Bb} 23 \mathrm{Sr}$ at $700 \mathrm{nM}$ each, probe Bb23Sp-FAM at $175 \mathrm{nM}$, and $2 \mu \mathrm{l}$ of template DNA. For all reactions, cycling conditions included an initial activation of the Taq DNA polymerase at $95^{\circ} \mathrm{C}$ for $15 \mathrm{~min}$, followed by 45 cycles of $1 \mathrm{~min}$ denaturation at $95^{\circ} \mathrm{C}$, followed by a $1 \mathrm{~min}$ annealing-extension step at $60^{\circ} \mathrm{C}$. Negative and positive controls were included in all runs.

Statistical analyses. Exact confidence intervals (CI) for prevalence rates at the $95 \%$ level were calculated. To study the difference of the molecular prevalence of B. burgdorferi s.l. according to bioclimatic zone, locality, farm, gender, age, breed and presence or not of ticks, chi square test or Fisher's exact test were performed using Epi Info 6.01 (CDC, Atlanta, USA), with a cutoff value of 0.05 . In order to consider any confusion factor, a chi square Mantel-Haenszel test was performed.

\section{RESULTS}

Ticks' collection. In this cross-sectional study, a total of 241 (92.7\%) sheep and 113 (37.3\%) goats were infested by at least one tick species. Ticks infecting sheep belonged to 3 species of Rhipicephalus: $R$. turanicus, $R$. sanguineus, and $R$. annulatus. Ticks collected from goats belonged to 2 genera and 4 species, namely, $R$. turanicus, $R$. bursa, $R$. sanguineus and Hyalomma 
Table 1. Prevalence of Borrelia burgdorferi sensu lato according to governorates, localities and farms in goats and sheep in Tunisia

\begin{tabular}{|c|c|c|c|c|c|}
\hline Host & Governorate & Locality & Farm No. & $\begin{array}{c}\text { No. of } \\
\text { animals }\end{array}$ & Positive $\left(\% \pm C . I .{ }^{\prime}\right)$ \\
\hline \multirow[t]{22}{*}{ Goats } & Bizerte & Alia & 1 & 30 & $0(0)$ \\
\hline & & & 2 & 09 & $0(0)$ \\
\hline & & & 3 & 15 & $0(0)$ \\
\hline & & & 4 & 16 & $1(6.3 \pm 0.12)$ \\
\hline & & & Total & 70 & $1(1.4 \pm 0.03)$ \\
\hline & & Sejnane & 9 & 23 & $1(4.3 \pm 0.08)$ \\
\hline & & & 10 & 25 & $15(60.0 \pm 0.19)$ \\
\hline & & & 11 & 32 & $17(53.1 \pm 0.17)$ \\
\hline & & & Total & 80 & $33(41.3 \pm 0.11)$ \\
\hline & & Joumine & 12 & 19 & $11(57.9 \pm 0.22)$ \\
\hline & & & 13 & 07 & $5(71.4 \pm 0.33)$ \\
\hline & & & 14 & 20 & $8(40.0 \pm 0.22)$ \\
\hline & & & 15 & 20 & $14(70.0 \pm 0.20)$ \\
\hline & & & 16 & 15 & $4(26.7 \pm 0.22)$ \\
\hline & & & Total & 81 & $42(51.9 \pm 0.11)$ \\
\hline & & Total & & 232 & $76(32.8 \pm 0.06)$ \\
\hline & Beja & Amdoun & 5 & 16 & $0(0)$ \\
\hline & & & 6 & 24 & $0(0)$ \\
\hline & & & 7 & 15 & $9(60 \pm 0.25)$ \\
\hline & & & 8 & 17 & $7(41.2 \pm 0.23)$ \\
\hline & & Total & & 72 & $16(22.2 \pm 0.10)$ \\
\hline & Total & & & 303 & $92(30.4 \pm 0.05)$ \\
\hline \multirow[t]{12}{*}{ Sheep } & Bizerte & Alia & 1 & 30 & $0(0)$ \\
\hline & & & 2 & 20 & $0(0)$ \\
\hline & & & 3 & 30 & $1(3,3 \pm 0.06)$ \\
\hline & & & 8 & 30 & $0(0)$ \\
\hline & & & 9 & 30 & $3(10 \pm 0.11)$ \\
\hline & & & Total & 140 & $4(2.6 \pm 0.03)$ \\
\hline & & Khetmine & 4 & 30 & $0(0)$ \\
\hline & & & 5 & 30 & $8(26.7 \pm 0.16)$ \\
\hline & & & 6 & 30 & $4(13.3 \pm 0.12)$ \\
\hline & & & 7 & 30 & $0(0)$ \\
\hline & & & Total & 120 & $12(10 \pm 0.05)$ \\
\hline & & Total & & 260 & $16(6.15 \pm 0.03)$ \\
\hline
\end{tabular}

'C.I.: $95 \%$ confidence interval.

excavatum. Ticks collected from cattle were classified as Hyalomma marginatum, $H$. excavatum and $H$. scupense. Rhipicephalus spp. engorged females were collected, but were not identified to species. Only 21 of the $232(9.1 \%)$ examined cattle were infested by at least one of these tick species. Ticks were observed in 85 camels $(37.6 \%)$ and identified as H. dromedarii, H. excavatum and H. impeltatum.

Molecular survey of Borrelia burgdorferi sensu lato. In goats, the B. burgdorferi s.l. overall infection rate was $30.4 \%$ (92/303) (Tab. 1). A statistically significant difference was noted among bioclimatic areas $(\mathrm{p}<0.001)$, localities $(\mathrm{p}<0.001)$ and farms $(\mathrm{p}<0.001)$. Goats located in humid areas $(39.1 \%$; 91/233) represented by the localities of Sejnane, Joumine and Amdoun were statistically more infected than those located in a sub-humid area $(1.4 \% ; 1 / 70)$, represented by the locality of El Alia. The highest prevalence was observed in Joumine
Table 2. Factors associated with molecular prevalence of Borrelia burgdorferi sensu lato in goats and sheep

\begin{tabular}{|c|c|c|c|c|c|c|}
\hline & & Goats & & & Sheep & \\
\hline Risk factor & No. & $\begin{array}{l}\text { Positive } \\
(\% \pm C . \text {.I. })\end{array}$ & P-value & No. & $\begin{array}{l}\text { Positive } \\
\left(\% \pm C . I .{ }^{\prime}\right)\end{array}$ & P-value \\
\hline Gender & & & 0.267 & & & 0.207 \\
\hline Male & 70 & $25(35.7 \pm 0.11)$ & & 50 & $5(10.0 \pm 0.08)$ & \\
\hline Female & 233 & $67(28.8 \pm 0.06)$ & & 210 & $11(5.2 \pm 0.03)$ & \\
\hline Age & & & $0.000^{*}$ & & & $0.002^{*}$ \\
\hline$\leq 2$ years & 133 & $56(42.1 \pm 0.08)$ & & 63 & $9(14.3 \pm 0.09)$ & \\
\hline$>2$ years & 170 & $36(21.2 \pm 0.06)$ & & 197 & $7(3.5 \pm 0.02)$ & \\
\hline Breed & & & 0.052 & & & $0.002^{*}$ \\
\hline Local/Barbarine ${ }^{2}$ & 275 & $88(32.0 \pm 0.06)$ & & 118 & $13(11.0 \pm 0.06)$ & \\
\hline Other breeds ${ }^{3}$ & 28 & $04(14.3 \pm 0.13)$ & & 142 & $3(2.1 \pm 0.02)$ & \\
\hline Tick infestation & & & $0.000^{*}$ & & & 0.275 \\
\hline Infested & 113 & $16(14.2 \pm 0.06)$ & & 244 & $14(5.7 \pm 0.03)$ & \\
\hline Not infested & 190 & $76(40.0 \pm 0.07)$ & & 16 & $2(12.5 \pm 0.16)$ & \\
\hline Total & 303 & $92(30.4 \pm 0.05)$ & & 260 & $16(6.2 \pm 0.03)$ & \\
\hline
\end{tabular}

${ }^{1}$ C.I.: $95 \%$ confidence interval.

${ }^{2}$ Local for goats and Barbarine for sheep.

${ }^{3}$ Other breeds are Alpine and Maltese for goats and Noire de Thibar, Queue fine de l'Ouest, Merinos, Sicilo-sarde and crossbred for sheep.

* Significant test.

(51.9\%, 42/81) (governorate of Bizerte), and farm No. 13 (Joumine locality) was the most infected farm $(71.4 \%, 5 / 7)$ (Tab. 1). Analysis of risk factors showed that B. burgdorferis.l. prevalence was higher in young goats ( $\leq 2$ years) $(42.1 \%$; $56 / 133)$ than in adults $(21.2 \%$; 36/170) $(\mathrm{p}<0.001)($ Tab. 2$)$. Goats infested by ticks were statistically less infected by B. burgdorferi s.l. $(14.2 \% ; 16 / 113)$, compared to those free of ticks $(40 \%$; 76/190) $(\mathrm{p}<0.001)$ (Tab. 2$)$.

In sheep, the B. burgdorferis.l. overall infection rate was $6.2 \%(16 / 260)$. A statistically significant difference was noted among localities $(\mathrm{p}=0.016)$ and among farms $(\mathrm{p}<0.001)$. The highest prevalence was observed in Khetmine (governorate of Bizerte) $(10 \% ; 12 / 120)$, and farm No. 5 (Khetmine locality) was the most infected farm $(26.7 \% ; 8 / 30)$ (Tab. 1$)$. B. burgdorferi s.l. prevalence was higher in young sheep ( $\leq 2$ years) $(14.3 \%$; $9 / 63)$ than adults ( $>2$ years) $(3.5 \%$; $7 / 197)$ $(\mathrm{p}=0.002)$ (Tab. 2). Additionally, the Barbarine breed (11.0\%; 13/118) was the most frequently infected, compared to other breeds (2.1\%; 3/142) $(\mathrm{p}=0.002)$ (Tab. 2). As for other ruminants, $B$. burgdorferi s.l. was detected in 4 adult camels $(1.8 \% ; 4 / 232)$ (2 females from Bouficha, belonging to a semiarid area, and 2 males from Douz belonging to the arid area), and 3 adult cattle $(1.3 \% ; 3 / 226)$ ( 2 females from Mateur and 1 female from El Alia both, belonging to the sub-humid area) (Tab. 3, 4).

\section{DISCUSSION}

To-date, there is still a lack of comprehensive knowledge on the distribution and prevalence of $B$. burgdorferi s.l. among ruminants in North Africa; therefore, in an attempt to fill this gap, the presented study reports for the first time the presence of B. burgdorferi s.l. in sheep, goats, cattle and camels in Tunisia. The results show that in sheep the prevalence of B. burgdorferi s.l. in El Alia and Khetmine were 2.6 and 
Table 3. Prevalence of Borrelia burgdorferi sensu lato according to bioclimatic zones, governorates and localities in cattle and camels in Tunisia

\begin{tabular}{lccccc}
\hline Host & $\begin{array}{c}\text { Bioclimatic } \\
\text { zone }\end{array}$ & Governorate & Locality & $\begin{array}{c}\text { No. of } \\
\text { animals }\end{array}$ & $\begin{array}{c}\text { Positive } \\
\left(\% \pm C . .{ }^{1}\right)\end{array}$ \\
\hline Cattle & Sub-humid & Bizerte & Alia & 70 & $1(1.4 \pm 0.03)$ \\
\hline & & Mateur & 76 & $2(2.6 \pm 0.03)$ \\
\hline & & Total & 146 & $3(2.0 \pm 0.02)$ \\
\hline Semi-arid & & Utique & 86 & $0(0)$ \\
\hline Total & & & $\mathbf{2 3 2}$ & $\mathbf{3}(\mathbf{1 . 3} \pm \mathbf{0 . 0 1})$ \\
\hline & Semi-arid & Sousse & Bouficha & 32 & $2(6.2 \pm 0.08)$ \\
\hline & Arid & Sidi Bouzid & Sidi Bouzid & 155 & $0(0)$ \\
\hline & Saharan & Kebili & Douz & 39 & $2(5.1 \pm 0.07)$ \\
\hline
\end{tabular}

C.I.: $95 \%$ confidence interval.

Table 4. Factors associated with molecular prevalence of Borrelia burgdorferi sensu lato in cattle and camels

\begin{tabular}{|c|c|c|c|c|c|c|}
\hline & \multicolumn{3}{|c|}{ Cattle } & \multicolumn{3}{|c|}{ Camels } \\
\hline Risk factor & No. & $\begin{array}{l}\text { Positive } \\
\left(\% \pm \text { C.I. }{ }^{1}\right)\end{array}$ & $P$-value & No. & $\begin{array}{l}\text { Positive } \\
\left(\% \pm \text { C.I. }{ }^{\prime}\right)\end{array}$ & $P$-value \\
\hline Gender & & & 0.629 & & & 0.641 \\
\hline Male & 33 & $0(0)$ & & 120 & $2(1.7 \pm 0.02)$ & \\
\hline Female & 199 & $3(1.5 \pm 0.02)$ & & 106 & $2(1.9 \pm 0.02)$ & \\
\hline Age & & & 0.477 & & & 0.112 \\
\hline$<1 / 2^{2}$ years & 30 & $0(0)$ & & 44 & $0(0)$ & \\
\hline [1 / $\left.2^{2}-7\right]$ years & 156 & $3(1.9 \pm 0.02)$ & & 109 & $4(3.7 \pm 0.03)$ & \\
\hline$>7$ years & 46 & $0(0)$ & & 73 & $0(0)$ & \\
\hline Tick infestation & & & 0.249 & & & 0.153 \\
\hline Infested & 21 & $1(4.8 \pm 0.09)$ & & 84 & $0(0)$ & \\
\hline Not infested & 211 & $2(0.9 \pm 0.01)$ & & 142 & $4(2.8 \pm 0.03)$ & \\
\hline Total & 232 & $3(1.3 \pm 0.01)$ & & 226 & $4(1.8 \pm 0.02)$ & \\
\hline
\end{tabular}

${ }^{1}$ C.I.: $95 \%$ confidence interval.

1 year for cattle; 2 years for camels.

$10.0 \%$, respectively, with an average prevalence of $6.2 \%$. This value is higher than the molecular prevalence reported by Chu et al. [24] in Chinese sheep kids (3.6\%), and lower than that found by $\mathrm{Fu}$ et al. [25] in sheep from China (39.0\%). However, most previous studies have been conducted using the serology method. The seroprevalence of B. burgdorferi s.l. was 23.8\% among sheep in Egypt [26], 22.1\% in Turkey [27], $16.7 \%$ in Slovakia [28], $14.1 \%$ in Italy [29], and $15.8-22.5 \%$ in China, as respectively reported by Li et al.[30] and Hua et al. [31]. Although sheep are considered an incompetent reservoir and do not seem to be able to transmit B. burgdorferi s.l. to ticks $[28,29]$, this animal species may represent a threat to humans by acting as a host maintaining tick populations, and as a spreader transferring pathogens from infected to uninfected ticks co-feeding on the same animal [15].

The B. burgdorferi s.l. molecular survey in goats showed that the prevalence in El Alia, Amdoun, Sejnane and Joumine were $1.4,22.2,41.3$ and $51.9 \%$, respectively, with an average of $30.4 \%$. To the best of our knowledge, this is the first molecular detection of B. burgdorferi s.l. in goats. To-date, the role of goats as competent reservoirs remains obscure. The high $B$. burgdorferi s.l. prevalence in goats indicates that goats were exposed to B. burgdorferi s.l. infection and that they might act as reservoir hosts for borreliosis. Using serological methods, several reports showed the detection of B. burgdorferi s.l. antibodies in goats. Seroprevalence has been estimated at $36.8 \%$ in Italy [29], 18.4\% in Slovakia [28], 18.0\% in Egypt [26], 5\% in Bolivia [32], and 19.1, 20.3 and 22.2\% in China, as reported by Long et al. [33], Li et al. [30] and Zhang et al. [34], respectively.

In the current study, a significant difference in B. burgdorferi s.l. infection rates in goats was recorded among bioclimatic areas. Goats located in humid areas, represented by the localities of Sejnane, Joumine and Amdoun, were statistically more infected than those located in a sub-humid area, represented by the locality of El Alia. This difference, which has been reported in other studies on horses [35] and pigs [36], is probably related to the effect of bioclimatic conditions on the distribution of tick vectors [37]. This study shows that goats infested by Rhipicephalus and Hyalomma ticks were statistically less infected by $B$. burgdorferi s.l. than those free of ticks. This result suggests that these tick species may not be involved or only weakly involved in the transmission of this complex, and that other tick species and/or bloodfeeding insects, such as bot-flies, fleas, and mosquitoes [38], are probably more incriminated in the transmission of B.burgdorferi s.l. in these investigated regions. Indeed, in Tunisia, Ixodes ricinus ticks are considered as the natural vector of B. burgdorferi s.l., especially B. lusitaniae $[17,39,40$, $41,42]$. Although ticks of this genus are known to be present in the Tunisian humid areas, none were found during this survey, probably because their peak activity occurs in autumn (November-October) [16]. This was previously observed by Fridriksdottir et al. [9], who reported the presence of seropositive animals in areas where I. ricinus ticks had never been recorded previously. In addition, overall prevalence rates of $B$. burgdorferi s.l. differed statistically according to localities and among sheep and goat farms. This discrepancy may result from differences in ecological factors, tick control programs, habitat types, husbandry practices, wildlife reservoir hosts, and/or microclimate, which may locally determine tick and host abundance $[43,44,45]$.

Prevalence of $B$. burgdorferi s.l. infection was significantly affected by the age of the sheep and goats. Young animals were significantly more infected than adults, suggesting that the analyzed small ruminants were exposed to the spirochetes early in life, and that borreliacidal activity of the animal complement and/or antibodies probably increased according to age. This result is in agreement with a serological study on Norwich sheep which reported that the majority of studied animals appeared to become infected during the first 2 years of life [9]. In sheep, the Barbarine breed is the most infected by $B$. burgdorferi complex, probably because sheep of this breed are not in their natural environment, which is the steppe of dry land in Central Tunisia, belonging mainly to the pre-Saharan area [46].

B. burgdorferi s.l. was detected in 3 adult cattle (1.3\%) situated in a sub-humid area. To our knowledge, this is the first report demonstrating the presence of $B$. burgdorferi s.l. DNA in cattle in Africa. Using the serological method, B. burgdorferi s.l. has also been suspected in other countries, such as Brazil (54.9\%) [47], Germany (33\%) [48], Slovakia (25.2\%) [49], Japan (20\%) [50] and the USA (7 and 71\%) [51, 52]. Positive serological or molecular tests provide support to diagnosis, but are not conclusive of the presence of current infection or clinical disease [20]. In fact, Lyme borreliosis in cattle is probably an infrequent disease that is difficult 
to diagnose due to the onset of unspecific symptoms [53]. In addition, cattle are not considered as reservoir hosts of B. burgdorferi s.l. [54], and the detection of some positive cases is probably due to the presence of other hosts in the same location [55].

B. burgdorferi s.l. DNA was detected in $1.8 \%$ of camels. This is the first report concerning B. burgdorferi s.l. in camels. Camels were exposed to $B$. burgdorferi s.l. infection and may be part of the natural cycle of this species complex in arid and Saharan areas. The absence of I. ricinus, which is one of the most incriminated tick species in the transmission of B. burgdorferi s.l. in Tunisia [17, 44], suggests that other vectors could transmit Lyme borreliosis in the ecosystems of camels.

\section{CONCLUSION}

This study demonstrates that B. burgdorferi s.l. DNA can be commonly found in Tunisian ruminants. Further studies are needed to determine the role of these animal species in the natural transmission of this complex to definitive hosts in Tunisia, and to identify and characterize the different genospecies infecting each ruminant species in the country.

\section{Acknowledgement}

This work was supported by the 'Laboratoire d'épidemiologie d'infections enzootiques des herbivores en Tunisie' (LR02AGR03), funded by the Ministry of Higher Education and Scientific Research, and the research project 'Epidémiologie de maladies bactériennes à transmission vectorielle des herbivores' (06-680-0029), funded by the Ministry of Agriculture of Tunisia. The authors would like to thank Prof. Mohamed Habib Jemli, Dr. Mounir Aloui, Dr. Maha Bousrih, Dr. Mouna Yahiaoui, Dr. Zakia Issaoui and Dr. Dorra Hattab for blood sampling and tick collection and Prof. Mohamed Gharbi and Mr. Mohamed Jedidi for assistance to the identification of ticks infesting sheep. Dr. Leilla Sayhi, Dr. Hichem Talhaoui, Dr. Rabeh Bouazizi and Dr. Samir Touil and their technicians have the authors' thanks for their assistance and facilitating access to the farmers. Prof. Ali Bouattour provided the B. burgdorferi s.l. DNA and assisted us in tick's identification.

\section{REFERENCES}

1. Kybicová K, Kurzová Z, Hulínská D. Molecular and serological evidence of Borrelia burgdorferi sensu lato in wild rodents in the Czech Republic. Vector Borne Zoonotic Dis. 2008; 8: 645-652.

2. Burgess EC, Gendron-Fitzpatrick A, Wright WO. Arthritis and systemic disease caused by Borrelia burgdorferi infection in a cow. J Am Vet Med Assoc. 1987; 191: 1468-1470.

3. Cohen ND, Heck FC, Heim B, et al.Seroprevalence of antibodies to Borrelia burgdorferi in a population of horses in central Texas. J Am Vet Med Assoc. 1992; 201: 1030-1034.

4. Levy SA, Dreesen DW. Lyme borreliosis in dogs. Canine practice 1992; 17: 5-14.

5. Baranton G, De Martino SJ. Borrelia burgdorferi sensu lato diversity and its influence on pathogenicity in humans. Curr Probl Dermatol. 2009; 37: 1-17.

6. Rudenko N, Golovchenko M, Lin T, et al. Delineation of a new species of the Borrelia burgdorferi Sensu Lato Complex, Borrelia americana sp. nov. J Clin Microbiol. 2009a; 47: 3875-3880.

7. Rudenko N, Golovchenko M, Grubhoffer L, Oliver JHJ. Borrelia carolinensis sp. nov., a new (14th) member of the Borrelia burgdorferi
Sensu Lato complex from the southeastern region of the United States. J Clin Microbiol. 2009b; 47: 134-141.

8. Stanek G,Reiter M. The expanding Lyme Borrelia complex--clinical significance of genomic species? Clin Microbiol Infect. 2011; 17: 487493.

9. Fridriksdottir V, Overnes G, Stuen S. Suspected Lyme borreliosis in sheep. Vet Record 1992; 130: 323-324.

10. Parker JL, White KK. Lyme borreliosis in cattle and horses: A review of the literature. Cornell Vet. 1992; 82: 253-274.

11. Burgess EC. Borrelia burgdorferi infection in Wisconsin horses and cows. Ann N Y Acad Sci. 1988; 539: 235-243.

12. Jaenson TG, Tälleklint L. Lyme borreliosis spirochetes in Ixodes ricinus (Acari:Ixodidae) and the varying hare on isolated islands in the Baltic, Sea. J Med Entomol. 1996; 33: 339-343.

13. Rijpkema SG, Herbes RG, Verbeek-De Kruif N, Schellekens JF. Detection of four species of Borrelia burgdorferi sensu lato in Ixodes ricinus ticks collected from roe deer (Capreolus capreolus) in the Netherlands. Epidemiol Infect. 1996; 117: 563-566.

14. Gern L, Rais O. Efficient transmission of Borrelia burgdorferi between cofeeding Ixodes ricinus ticks (Acari: Ixodidae). J Med Entomol. 1996; 33: 189-192.

15. Ogden NH, Nuttall PA, Randolph SE. Natural Lyme disease cycles maintained via sheep by co-feeding ticks. Parasitology 1997; 115: 591-599.

16. Bouattour A, Darghouth MA, Daoud A. Distribution and ecology of ticks (Acari: Ixodidae) infesting livestock in Tunisia: an overview of eighth years field collections. Parassitologia 1999; 41: 5-10.

17. Younsi H, Postic D, Baranton G, Bouattour A. High prevalence of Borrelia lusitaniae in Ixodes ricinus ticks in Tunisia. Eur J Epidemiol. 2001; 17: 53-56

18. Sarih M, Jouda F, Gern L, Postic D. First isolation of Borrelia burgdorferi sensu lato from Ixodes ricinus ticks in Morocco. Vector Borne Zoonotic Dis. 2003; 3, 133-139.

19. Collares-Pereira M, Couceiro S, Franca I, et al. First isolation of Borrelia lusitaniae from a human patient. J Clin Microbiol. 2004; 42: 1316-1318.

20. Piesman J, Gern L. Lyme borreliosis in Europe and North America. Parasitology 2004; 129: 191-220.

21. Gray JS, Kahl O, Lane RS, Stanek G. Lyme borreliosis: biology, epidemiology and control. CABI Publishing, Oxford, England 2002; p. 251.

22. Courtney JW, Kostelnik LM, Zeidner NS, Massung RF. Multiplex realtime PCR for detection of Anaplasma phagocytophilum and Borrelia burgdorferi. J Clin Microbiol. 2004; 42: 3164-3168.

23. Walker AR, Bouattour A, Camicas J-L, et al. Ticks of domestic animals in Africa: A guide to identification of species. Bioscience reports. Part 4: species of ticks 2013; p. 45-221.

24. Chu CY, Jiang BG, Qiu EC, et al. Borrelia burgdorferi sensu lato in sheep keds (Melophagus ovinus), Tibet, China. Vet Microbiol. 2011; 149: 526-529.

25. Fu Y, Liu Z, Guan G, et al. Development of real-time polymerase chain reaction for detection of Borrelia burgdorferi sensu lato in China. Vector Borne Zoonotic Dis. 2012; 12: 341-345.

26. Helmy N. Seasonal abundance of Ornithodorus (O.) savignyi and prevalence of infection with Borrelia spirochetesin Egypt. J Egypt SocParasitol. 2000; 30: 607-619.

27. Tuncer D, Öğünç D, Çolak D, et al. Prevalence of Borrelia burgdorferi antibodies in urban and high risk areas. Turk J Infect. 1999; 13: 325-328.

28. Trávnicek M, Stefancíková A, Nadzamová D, et al. Seroprevalence of antiBorrelia burgdorferi antibodies in sheep and goats from mountainous areas of Slovakia. Ann Agric Environ Med. 2002; 9: 153-155.

29. Ciceroni L, Simeoni J, Pacetti AI, et al. Antibodies to Borrelia burgdorferi in sheep and goats. Alto Adige - South Tyrol, Italy. New Microbiol. 1996; 19: 171-174.

30. Li ZG, Ma FH, Wu MY. Study on Lyme disease in the Limpan Mountains of Ningxia. Chin J Vector Biol Control 1997; 8: 441-443.

31. Hua MT, Lin T, Lin CL. Studies on the seroepidemiology of Lyme disease of human and animals in Arlartai area of Xinjiang province. Chin J Vector Biol Control 1998; 9: 268-270.

32. Ciceroni L, Bartoloni A, Ciarrocchi S, et al. Serologic survey for antibodies to Borrelia burgdorferi in sheep, goats and dogs in Cordillera Province, Bolivia. Zentralbl Veterinarmed B 1997; 44: 133-137.

33. Long J, Lin T, Li WB. Investigation on human and animal Lyme disease in Shanggao County of Jiangxi Province. Chin J Vector Biol Control 1999; 10: 45-47.

34. Zhang DR, Lin T, Li Q. Investigation on the seroepidemiology of Lyme disease in Anhui province. Chin. J. Vector Biol. Control 1998; 9: 265-267. 
35. Jensen PM, Frandsen F. Temporal risk assesment for Lyme borreliosis in Denmark. Scand J Infect Dis. 2009; 32: 539-544.

36. Juricová Z, Hubálek Z. Serologic survey of the wild boar (Sus scrofa) for Borrelia burgdorferi sensu lato. Vector Borne Zoonotic Dis. 2009; 9: 479-482.

37. Vennestrøm J, Egholm H, Jensen PM. Occurrence of multiple infections with different Borrelia burgdorferi genospecies in Danish Ixodes ricinus nymphs. Parasitol Int. 2008; 57: 32-37.

38. Magnarelli LA, Anderson JF. Ticks and biting insects infected with the etiologic agent of Lyme disease, Borrelia burgdorferi. J Clin Microbiol. 1988; 26: 1482-1486.

39. Zhioua E, Bouattour A, Hu CM, et al. Infection of Ixodes ricinus (Acari: Ixodidae) by Borrelia burgdorferi sensu lato in North Africa. J Med Entomol. 1999; 36: 216-218.

40. Bouattour A, Ghorbel A, Chabchoub A, Postic D. [Lyme borreliosis situation in North Africa]. Arch Inst Pasteur Tunis 2004; 81: 13-20.

41. Younsi H, Sarih M, Jouda F, et al. Characterization of Borrelia lusitaniae isolates collected in Tunisia and Morocco. J Clin Microbiol. 2005; 43: 1587-1593.

42. Fingerle V, Michel H, Hettche G, et al. Borrelia burgdorferi s.l. OspAtypes are widespread in Bavaria but show distinct local patterns. Int $J$ Med Microbiol. 2004; 293: 165-166.

43. Rauter C, Hartung T. Prevalence of Borrelia burgdorferi sensu lato genospecies in Ixodes ricinus ticks in Europe: a metaanalysis. Appl Environ Microbiol. 2005; 71: 7203-7216.

44. Eisen L, Eisen RJ, Lane RS. Geographical distribution patterns and habitat suitability models for presence of host-seeking ixodid ticks in dense woodlands of Mendocino County, California. J Med Entomol. 2006; 43: 415-427.

45. Ekner A, Dudek K, Sajkowska Z, et al. Anaplasmataceae and Borrelia burgdorferi sensu lato in the sand lizard Lacerta agilis and co-infection of these bacteria in hosted Ixodes ricinus ticks. Parasit Vectors 2011; 4: 182 .
46. Ben Salem H, Lassoued N, Rekik M. Merits of the fat-tailed Barbarine sheep raised in different production systems in Tunisia: digestive, productive and reproductive characteristics. Trop Anim Health Prod. 2011; 43: 1357-1370.

47. Guedes DSJ, Araújo FR, Silva FJ, et al. Frequency of antibodies to Babesia bigemina, B. bovis, Anaplasma marginale, Trypanosoma vivax and Borrelia burgdorferi in cattle from the Northeastern region of the State of Pará, Brazil. Rev Bras Parasitol Vet. 2008; 17: 105-109.

48. Krampitz HE, Bark S. [Epidemiology of Ixodes-Borreliosis in Southern Germany]. Immun Infekt. 1987; 15: 141-145.

49. Stefancíková A, Stěpánová G, Derdáková M, etal. Serological evidence for Borrelia burgdorferi infection associated with clinical signs in dairy cattle in Slovakia. Vet Res Commun. 2002; 26: 601-611.

50. Takahashi K, Isogai E, Isogai $\mathrm{H}$, et al. Serological survey for Borrelia burgdorferi infection in cattle in southern Hokkaido. J Vet Med Sci. 1993; 55: 921-924.

51. Ji B, Collins MT. Seroepidemiologic survey of Borrelia burgdorferi exposure of dairy cattle in Wisconsin. Am J Vet Res. 1994; 55: 12281231.

52. Magnarelli LA, Bushmich SL, Sherman BA, Fikrig E. A comparison of serologic tests for the detection of serum antibodies to whole-cell and recombinant Borrelia burgdorferi antigens in cattle. Can Vet J. 2004; 45: 667-673.

53. Buschmich SL. Lyme borreliosis in domestic animals. J Spirochet Tickborne Dis. 1994; 1: 24-28.

54. Gern L. Life cycle of Borrelia burgdorferi sensu lato and transmission to humans. Curr Probl Dermatol. 2009; 37: 18-30.

55. Gray JS, Kahl O, Janetzki C, et al. The spatial distribution of Borrelia burgdorferi infected Ixodes ricinus in the Connemara region of County Galway, Ireland. Exp ApplAcarol. 1995; 19: 163-172. 